\title{
A Genetic Variant of BTLA Gene is Related with Increased Risk and Clinical Manifestations of Breast Cancer in Chinese Women
}

\author{
Rui-Peng Zhao \\ Huaian First People's Hospital \\ Zhi Li \\ Huaian First People's Hospital \\ Chang Li \\ Huaian First People's Hospital \\ Kang Xu \\ Huaian First People's Hospital \\ Lin-Lin Zhen \\ Huaian First People's Hospital \\ Wei Song \\ Huaian First People's Hospital \\ Jianhua Shi ( $\sim$ shijianhua122@163.com ) \\ Huaian First People's Hospital
}

\section{Research}

Keywords: BTLA, breast cancer, rs1982809 polymorphism, case-control study

Posted Date: December 4th, 2020

DOI: https://doi.org/10.21203/rs.3.rs-120282/v1

License: (c) (1) This work is licensed under a Creative Commons Attribution 4.0 International License. Read Full License 


\section{Abstract}

Background: B and T lymphocyte attenuator (BTLA), an immunoinhibitory receptor, is shown to suppress the lymphocyte activation. Several studies addressed the relationship between BTLA rs1982809 polymorphism and cancer's risk.

Methods: To identify the effects of this polymorphism on the risk of breast cancer (BC), this study was designed in Chinese women from China, Jiangsu Province. This study involved 324 BC patients and 412 controls.

Results: We observed that BTLA rs1982809 polymorphism elevated the risk of BC. Similar finding was also shown in the subgroup of premenopausal women and those aged $<55$ years old. In addition, this polymorphism correlated with the estrogen receptor (ER) status, C-erbB-2 status, Ki-67 status, tumor node metastasis (TNM) stage and tumor size of BC patients.

Conclusions: Collectively, BTLA rs1982809 polymorphism shows a significant association with elevated risk and clinical features of $\mathrm{BC}$ in Chinese women. Further studies involving other races are urgently needed to replicate these findings.

\section{Introduction}

Breast cancer $(\mathrm{BC})$ is the second frequent cancer, and it is also the most common malignancy in women worldwide [1]. Nearly 2.1 million new diagnosed BC patients and approximately 627,000 BC-related deaths occurred in 2018 [2]. BC is a heterogeneous disorder clinically, which has diverse pathology subtypes and molecular subtypes with varied aetiologies, risk factors, and responses to prognoses and treatments $[3,4]$. Due to the implementation of mammographic screening and improvement of treatment methods for $\mathrm{BC}$, the diagnosis and prognosis of BC improved increasingly. Endogenous hormone levels, exogenous hormone intake, high alcohol consumption, smoking, less physical activity, some breast diseases, and genetic susceptibility are all risk factors for BC [5-7]. Up to date, several GWAS studies have demonstrated important loci associated with BC susceptibility [8-12].

$B$ and T lymphocyte attenuator (BTLA) is a suppressor molecule, which belongs to the immunoglobulin superfamily. BTLA is mainly expressed in B lymphocytes, $T$ lymphocytes, macrophages and dendritic cells. BTLA is an immunoinhibitory receptor which could suppress lymphocyte activation by delivering inhibitory signals, with similarities to programmed cell death-1 (PD-1) or cytotoxic T lymphocyte antigen-4 (CTLA-4) [13, 14]. BTLA could negatively regulate immune responses, and BTLA-deficient $T$ cells led to the elevated proliferation of T cells [15]. Herpes virus entry mediator (HVEM), the ligand of BTLA, could interact with BTLA, thereby resulting in the inhibition of T-cell activation and cytokine production $[13,16,17]$. Liu et al. indicated that BTLA/HVEM pathway was associated with peripheral T cell suppression in hepatocellular carcinoma patients, which may serve as a promising target for hepatocellular carcinoma immunotherapy [18]. Sekar et al. observed the effects of BTLA on type I Natural Killer T cells in limiting anti-tumor immunity [19]. Considering the important role of BTLA in cancer immunology, we assumed that genetic variations in BTLA gene may be associated with cancer susceptibility. 
The BTLA gene is located on the chromosome 3q13.2. Previous studies have investigated whether BTLA rs1982809 polymorphism was linked with the risk of cancer, including renal cell carcinoma [20], chronic lymphocytic leukemia [21], esophagogastric junction adenocarcinoma [22], esophageal squamous cell carcinoma [23] and lung cancer [24]. However, no studies explored the association of this polymorphism and BC risk. Thus, we aimed to determine whether BTLA rs1982809 polymorphism conferred susceptibility to BC in Chinese women.

\section{Material And Methods Subjects}

This research enrolled a total of 324 BC patients and 412 age-matched controls from Huaian No.1 People's Hospital. BC was diagnosed according to imaging and pathological manifestations. Clinical information of all individuals was recorded from electronic medical records and questionnaires. In addition, 412 healthy volunteers, receiving health examination in the same hospital, were selected as controls. Controls with other cancers or family history of cancer were not recruited in this study. The Institutional Review Board of our hospital approved this study. Informed consents were obtained from all individuals. This research was also in compliance with the standards of Declaration of Helsinki.

\section{Genotyping}

Venous samples were got from all subjects. Peripheral venous blood samples from all subjects were used to extract DNA. BTLA rs1982809 polymorphism was genotyped using the PCR method. The primers for this polymorphism were 5'- GCTCTCGAGTCCCGTCCCAGTAGTTGAAGGGTCCTGCTA-3'(F) and 5'-

TGCCAGCTGCTTCGAGCGAAGCCATTGCTGC-3'(R). We genotyped 10\% chosen samples again to evaluate the genotyping error; and the concordance rate was $100 \%$.

\section{Statistical analysis}

$\chi^{2}$ test and $t$ test were utilized to analyze the categorical variables and continuous variables, respectively. A goodness-of-fit $\chi^{2}$ test was intended to estimate the deviation from HWE in controls. The odds ratios (ORs), as well as $95 \%$ confidence intervals $(95 \% \mathrm{Cls})$, were determined with logistic regression analysis with adjustment of age and Body Mass Index (BMI), and menopausal status or not. $P$ value $<0.05$ was regarded as significant. Statistical analysis was performed by SPSS 22.0.

\section{Results}

\section{Characteristics of all enrolled individuals}

The characteristic information and clinical features of all subjects are listed in Table 1. This study recruited 324 cases and 412 controls aged $50.48 \pm 10.16$ and $49.62 \pm 9.54$ years old, respectively. No obvious 
differences were obtained among age, $\mathrm{BMI}$ and menopausal status $(P>0.05)$. Other clinical features of $\mathrm{BC}$ are also summarized in Table 1. 
Table 1

Distribution of selected demographic variables among breast cancer patients and controls.

\begin{tabular}{|c|c|c|c|}
\hline Characteristics & Case $(\mathrm{N}=324)$ & Control $(N=412)$ & $P$ \\
\hline Age & $50.48 \pm 10.16$ & $49.62 \pm 9.54$ & 0.244 \\
\hline BMI & $24.75 \pm 3.16$ & $24.99 \pm 2.94$ & 0.287 \\
\hline Menopausal status & & & 0.276 \\
\hline Premenopausal & $179(55.2 \%)$ & $211(51.2 \%)$ & \\
\hline Postmenopausal & $145(44.8 \%)$ & $201(48.8 \%)$ & \\
\hline \multicolumn{4}{|l|}{ Site of tumor } \\
\hline Left & $170(52.5 \%)$ & & \\
\hline Right & $154(47.5 \%)$ & & \\
\hline \multicolumn{4}{|l|}{ ER } \\
\hline Positive & $220(16.8 \%)$ & & \\
\hline Negative & 104(83.2\%) & & \\
\hline \multicolumn{4}{|l|}{ PR } \\
\hline Positive & $192(59.3 \%)$ & & \\
\hline Negative & $132(40.7 \%)$ & & \\
\hline \multicolumn{4}{|l|}{ C-erbB-2 } \\
\hline Positive & $57(17.6 \%)$ & & \\
\hline Negative & $267(82.4 \%)$ & & \\
\hline \multicolumn{4}{|l|}{ Ki67 } \\
\hline$>30 \%$ & $83(25.6 \%)$ & & \\
\hline$\leq 30 \%$ & $241(74.4 \%)$ & & \\
\hline \multicolumn{4}{|l|}{ Histologic type } \\
\hline IDC & 298(92.0\%) & & \\
\hline ILC & $12(3.7 \%)$ & & \\
\hline Others & $14(4.3 \%)$ & & \\
\hline \multicolumn{4}{|l|}{ Histologic grade } \\
\hline G1 & $38(11.7 \%)$ & & \\
\hline
\end{tabular}

BMI, Body Mass Index; ER, Estrogen receptor; PR, Progesterone receptor; IDC, Invasive ductal carcinoma; ILC, Invasive lobular carcinoma. 


\begin{tabular}{|lll|}
\hline Characteristics & Case $(\mathbf{N}=324)$ & Control $(\mathbf{N}=412)$ \\
\hline G2 & $212(65.4 \%)$ & $P$ \\
\hline G3 & $74(22.8 \%)$ & \\
\hline TNM & $84(25.9 \%)$ \\
\hline$\square$ & $167(51.5 \%)$ \\
\hline$\square$ & $73(22.5 \%)$ \\
\hline$\square$ & $177(54.6 \%)$ \\
\hline Tumor size & $147(45.4 \%)$ \\
\hline$>2$ cm & \\
\hline & \\
\hline $\begin{array}{l}\text { BMI, Body Mass Index; ER, Estrogen receptor; PR, Progesterone receptor; IDC, Invasive ductal carcinoma; } \\
\text { ILC, Invasive lobular carcinoma. }\end{array}$ \\
\hline
\end{tabular}

\section{Relationship Between Btla Rs1982809 Polymorphism And Bc Risk}

BTLA rs1982809 polymorphism was in line with the HWE test in controls $\left(P_{H W E}=0.657\right)$. The genotype and allele distributions of this polymorphism are presented in Table 2. Overall, BTLA rs1982809 polymorphism presented significant association with increased susceptibility to $B C$ after adjustment of $B M I$, age, and menopausal status (AA versus GG, adjusted OR, 1.95; $95 \% \mathrm{Cl}, 1.05-3.61 ; P=0.026$ ). Next, we found that A allele carriers showed elevated risk for $\mathrm{BC}$ (A versus $\mathrm{G}, \mathrm{OR}, 1.35 ; 95 \% \mathrm{Cl}, 1.06-1.71 ; P=0.014$ ). 
Table 2

Logistic regression analysis of associations between BTLA rs1982809 polymorphism and risk of breast cancer.

\begin{tabular}{|c|c|c|c|c|c|c|c|}
\hline Models & Genotype & Case $(n, \%)$ & $\begin{array}{l}\text { Control (n, } \\
\%)\end{array}$ & OR (95\% Cl) & $\begin{array}{l}P \\
\text { value }\end{array}$ & $\begin{array}{l}* \mathrm{OR}(95 \% \\
\mathrm{Cl})\end{array}$ & $\begin{array}{l}* P \\
\text { value }\end{array}$ \\
\hline Co-dominant & GG & $171(52.8 \%)$ & $249(60.4 \%)$ & 1.00 & - & 1.00 & - \\
\hline Heterozygote & $\mathrm{GA}$ & $126(38.9 \%)$ & $143(34.7 \%)$ & $\begin{array}{l}1.28(0.94- \\
1.75)\end{array}$ & 0.113 & $\begin{array}{l}1.25(0.91- \\
1.73)\end{array}$ & 0.111 \\
\hline Homozygote & AA & $27(8.3 \%)$ & $20(4.9 \%)$ & $\begin{array}{l}1.97(1.07- \\
3.62)\end{array}$ & 0.028 & $\begin{array}{l}1.95(1.05- \\
3.61)\end{array}$ & 0.026 \\
\hline \multirow[t]{2}{*}{ Dominant } & GG & $171(52.8 \%)$ & $249(60.4 \%)$ & 1.00 & - & 1.00 & - \\
\hline & $A A+G A$ & $153(47.2 \%)$ & $163(29.6 \%)$ & $\begin{array}{l}1.37(1.02- \\
1.83)\end{array}$ & 0.037 & $\begin{array}{l}1.35(1.01- \\
1.81)\end{array}$ & 0.034 \\
\hline \multirow[t]{2}{*}{ Recessive } & $\mathrm{GA}+\mathrm{GG}$ & 297(91.7\%) & 392(95.1\%) & 1.00 & - & 1.00 & - \\
\hline & AA & $27(8.3 \%)$ & $20(4.9 \%)$ & $\begin{array}{l}1.78(0.98- \\
3.24)\end{array}$ & 0.055 & $\begin{array}{l}1.75(0.95- \\
3.21)\end{array}$ & 0.054 \\
\hline \multirow[t]{2}{*}{ Allele } & G & $468(72.2 \%)$ & $641(77.8 \%)$ & 1.00 & - & - & - \\
\hline & A & $180(27.8 \%)$ & $183(22.2 \%)$ & $\begin{array}{l}1.35(1.06- \\
1.71)\end{array}$ & 0.014 & - & - \\
\hline
\end{tabular}

In addition, we interpreted the effects of the BTLA rs1982809 polymorphism on the risk of BC in the subgroups by BMI, age, and menopausal status (Table 3). Data detected that the rs 1982809 polymorphism was more likely to intensify the risk of $\mathrm{BC}$ among premenopausal women and those aged $<55$ years old. 
Table 3

Stratified analyses between BTLA rs1982809 polymorphism and the risk of breast cancer.

\begin{tabular}{|c|c|c|c|c|c|c|c|}
\hline \multirow[t]{2}{*}{ Variable } & \multicolumn{3}{|c|}{ (case/control) } & \multirow[t]{2}{*}{ GA vs. GG } & \multirow[t]{2}{*}{ AA vs. GG } & \multirow{2}{*}{$\begin{array}{l}\text { AA vs. GG } \\
+\mathrm{GA}\end{array}$} & \multirow{2}{*}{$\begin{array}{l}A A+G A \\
\text { vs. } G G\end{array}$} \\
\hline & GG & $\mathrm{GA}$ & $\mathrm{AA}$ & & & & \\
\hline \multicolumn{8}{|l|}{ BMI } \\
\hline$<25$ & $98 / 119$ & $73 / 74$ & $14 / 9$ & $\begin{array}{l}1.20(0.79- \\
1.82) ; \\
0.399\end{array}$ & $\begin{array}{l}1.89(0.78- \\
4.55) ; \\
0.151\end{array}$ & $\begin{array}{l}1.76(0.74- \\
4.16) ; \\
0.196\end{array}$ & $\begin{array}{l}1.30(0.87- \\
1.95) ; \\
0.197\end{array}$ \\
\hline$\geq 25$ & $73 / 130$ & $53 / 69$ & $13 / 11$ & $\begin{array}{l}1.37(0.87- \\
2.16) ; \\
0.180\end{array}$ & $\begin{array}{l}2.10(0.90- \\
4.94) \\
0.082\end{array}$ & $\begin{array}{l}1.87(0.81- \\
4.30) ; \\
0.137\end{array}$ & $\begin{array}{l}1.47(0.95- \\
2.27) \\
0.082\end{array}$ \\
\hline \multicolumn{8}{|l|}{ Age (years) } \\
\hline$<55$ & $116 / 174$ & $92 / 91$ & $21 / 17$ & $\begin{array}{l}1.52(1.04- \\
2.02) ; \\
0.028\end{array}$ & $\begin{array}{l}1.85(0.94- \\
3.66) ; \\
0.073\end{array}$ & $\begin{array}{l}1.57(0.81- \\
3.06) ; \\
0.178\end{array}$ & $\begin{array}{l}1.57(1.10- \\
2.23) ; \\
0.012\end{array}$ \\
\hline$\geq 55$ & $55 / 75$ & $34 / 52$ & $6 / 3$ & $\begin{array}{l}0.89(0.51- \\
1.55) ; \\
0.685\end{array}$ & $\begin{array}{l}2.73(0.65- \\
11.38) \\
0.282\end{array}$ & $\begin{array}{l}2.85(0.70- \\
11.72) ; \\
0.130\end{array}$ & $\begin{array}{l}0.99(0.58- \\
1.69) ; \\
0.976\end{array}$ \\
\hline \multicolumn{8}{|l|}{$\begin{array}{l}\text { Menopausal } \\
\text { status }\end{array}$} \\
\hline Premenopausal & $89 / 130$ & $70 / 68$ & $20 / 13$ & $\begin{array}{l}1.50(0.98- \\
2.31) ; \\
0.062\end{array}$ & $\begin{array}{l}2.25(1.06- \\
4.75) ; \\
0.031\end{array}$ & $\begin{array}{l}1.92(0.92- \\
3.97) ; \\
0.076\end{array}$ & $\begin{array}{l}1.62(1.08- \\
2.43) ; \\
0.018\end{array}$ \\
\hline Postmenopausal & $82 / 119$ & $56 / 75$ & $7 / 7$ & $\begin{array}{l}1.08(0.69- \\
1.69) ; \\
0.724\end{array}$ & $\begin{array}{l}1.45(0.49- \\
4.29) ; \\
0.499\end{array}$ & $\begin{array}{l}1.41(0.48- \\
4.10) ; \\
0.531\end{array}$ & $\begin{array}{l}1.12(0.72- \\
1.72) \\
0.622\end{array}$ \\
\hline
\end{tabular}

\section{Association with BTLA rs1982809 polymorphism and clinicopathological features of BC}

Last, we depicted the link between this SNP and the clinical feature of BC (Table 4). Data revealed that BTLA rs 1982809 polymorphism was connected to the ER status, Ki-67 status, TNM stage and tumor size of BC patients. No significance association was shown in other clinical features of $B C$, including histological grade, and tumor site and so on. 
Table 4

The associations between BTLA rs1982809 polymorphism and clinical characteristics of breast cancer.

$\begin{array}{ll}\text { Characteristics } & \begin{array}{l}\text { Genotype } \\ \text { distributions }\end{array}\end{array}$

$\begin{array}{llll}\text { GG } & \text { GA } & \text { AA } & \text { GA }+A A\end{array}$

Histologic grade

$\begin{array}{lllll}\text { G2/G1 } & 112 / 19 & 85 / 15 & 15 / 4 & 100 / 19 \\ \text { OR (95\%Cl); P- } & 1.0 \text { (reference) } & 0.96(0.46-2.00) ; & 0.64(0.19-2.12) ; & 0.89(0.45-1.78) ; \\ \text { value } & & 0.916 & 0.689 & 0.748\end{array}$

Histological

grade

\begin{tabular}{|c|c|c|c|c|}
\hline G3/G1 & $40 / 19$ & $26 / 15$ & $8 / 4$ & $34 / 19$ \\
\hline $\begin{array}{l}\text { OR }(95 \% \mathrm{Cl}) ; P \text { - } \\
\text { value }\end{array}$ & 1.0 (reference) & $\begin{array}{l}0.82(0.36-1.90) \\
0.649\end{array}$ & $\begin{array}{l}0.95(0.25-3.55) \\
1.000\end{array}$ & $\begin{array}{l}0.85(0.39-1.86) \\
0.684\end{array}$ \\
\hline
\end{tabular}

Site of tumor

\begin{tabular}{lllll} 
Left/Right & $91 / 80$ & $65 / 61$ & $14 / 13$ & $79 / 74$ \\
\hline $\begin{array}{l}\text { OR }(95 \% \mathrm{Cl}) ; P- \\
\text { value }\end{array}$ & 1.0 (reference) & $0.94(0.59-1.49) ;$ & $0.95(0.42-2.13) ;$ & $0.94(0.61-1.45) ;$ \\
\hline
\end{tabular}

ER

\begin{tabular}{lllll} 
Positive/Negative & $107 / 64$ & $95 / 31$ & $18 / 9$ & $113 / 40$ \\
\hline $\begin{array}{l}\text { OR }(95 \% \mathrm{Cl}) ; P- \\
\text { value }\end{array}$ & 1.0 (reference) & $\mathbf{1 . 8 3 ( 1 . 1 0 -}$ & $1.20(0.51-2.82) ;$ & $\mathbf{1 . 6 9 ( 1 . 0 5 - 2 . 7 2 ) ;}$ \\
\hline
\end{tabular}

PR

$\begin{array}{lllll}\text { Positive/Negative } & 98 / 73 & 79 / 47 & 15 / 12 & 94 / 59 \\ \text { OR }(95 \% \mathrm{Cl}) ; P- & 1.0 \text { (reference) } & 0.77(0.46-1.31) ; & 0.94(0.51-1.76) ; & 1.19(0.76-1.85) ; \\ \text { value } & & 0.335 & 0.856 & 0.450\end{array}$

C-erbB-2

\begin{tabular}{|c|c|c|c|c|}
\hline Positive/Negative & $22 / 149$ & $30 / 96$ & $5 / 22$ & $35 / 118$ \\
\hline $\begin{array}{l}\text { OR }(95 \% \mathrm{Cl}) ; P- \\
\text { value }\end{array}$ & 1.0 (reference) & $\begin{array}{l}2.12(1.15-3.88) ; \\
0.014\end{array}$ & $\begin{array}{l}1.54(0.53-4.48) \\
0.426\end{array}$ & $\begin{array}{l}2.01(1.12-3.61) \\
0.018\end{array}$ \\
\hline \multicolumn{5}{|l|}{ Ki67 } \\
\hline$>30 \% / \leq 30 \%$ & $39 / 132$ & $32 / 94$ & $12 / 15$ & $44 / 109$ \\
\hline $\begin{array}{l}\text { OR }(95 \% \mathrm{Cl}) ; P \text { - } \\
\text { value }\end{array}$ & 1.0 (reference) & $\begin{array}{l}1.15(0.67-1.97) \\
0.605\end{array}$ & $\begin{array}{l}2.71(1.17-6.27) ; \\
0.017\end{array}$ & $\begin{array}{l}1.37(0.83-2.25) \\
0.221\end{array}$ \\
\hline
\end{tabular}

ER, Estrogen receptor; PR, Progesterone receptor; IDC, Invasive ductal carcinoma; Bold values are statistically significant $(P<0.05)$. 


\begin{tabular}{|c|c|c|c|c|}
\hline Characteristics & $\begin{array}{l}\text { Genotype } \\
\text { distributions }\end{array}$ & & & \\
\hline \multicolumn{5}{|l|}{ TNM } \\
\hline$\nabla / \bigotimes+\rrbracket$ & $33 / 138$ & $28 / 98$ & $12 / 15$ & $40 / 113$ \\
\hline $\begin{array}{l}\text { OR }(95 \% \mathrm{Cl}) ; \mathrm{P}- \\
\text { value }\end{array}$ & 1.0 (reference) & $\begin{array}{l}1.20(0.68-2.11) \\
0.538\end{array}$ & $\begin{array}{l}3.35(1.43-7.82) ; \\
0.004\end{array}$ & $\begin{array}{l}1.48(0.88-2.50) \\
0.141\end{array}$ \\
\hline \multicolumn{5}{|l|}{ Tumor size } \\
\hline$>2 \mathrm{~cm} / \leq 2 \mathrm{~cm}$ & $83 / 88$ & $81 / 45$ & $13 / 14$ & $94 / 59$ \\
\hline $\begin{array}{l}\text { OR }(95 \% \mathrm{Cl}) ; \mathrm{P}- \\
\text { value }\end{array}$ & 1.0 (reference) & $\begin{array}{l}1.91(1.19-3.06) ; \\
0.007\end{array}$ & $\begin{array}{l}0.99(0.44-2.22) \\
0.970\end{array}$ & $\begin{array}{l}1.69(1.09-2.63) \\
0.020\end{array}$ \\
\hline \multicolumn{5}{|l|}{ Histologic type } \\
\hline IDC/Not & $159 / 12$ & $114 / 12$ & $25 / 2$ & $139 / 14$ \\
\hline $\begin{array}{l}\text { OR }(95 \% \mathrm{Cl}) ; \mathrm{P}- \\
\text { value }\end{array}$ & 1.0 (reference) & $\begin{array}{l}0.72(0.31-1.65) \\
0.433\end{array}$ & $\begin{array}{l}0.94(0.20-4.47) \\
1.000\end{array}$ & $\begin{array}{l}0.75(0.34-1.67) \\
0.481\end{array}$ \\
\hline
\end{tabular}

\section{Discussion}

In this presented study, we observed that BTLA rs1982809 polymorphism intensified the risk of BC in Chinese women. Further subgroup analyses obtained that this increased risk effect was more evident in premenopausal women and those aged < 55 years old. Additionally, we found that rs 1982809 polymorphism was linked to ER status, C-erbB-2 status, Ki-67 status, TNM stage and tumor size of BC patients.

Previous studies showed that the HVEM-BTLA pathway was involved in the progression of inflammation, autoimmunity, and immune tolerance $[25,18,26,27]$. BTLA was shown to participate in tumor immunity and genesis [28-32]. Polymorphisms of BTLA gene might exert effects on the predisposition to immune-related disorders, including cancer.

Recently, several studies paid attention to the link between BTLA rs1982809 polymorphism and cancer risk. Partyka et al. showed that this SNP strengthened the risk of renal cell carcinoma in a Polish population [20]. A similar finding was shown in another study by their research team, and they found that BTLA rs1982809 polymorphism elevated the risk of chronic lymphocytic leukemia [21]. A Caucasian study from Tunisia also replicated this positive result; they observed that rs1982809 polymorphism was shown to elevate the risk of lung cancer in Tunisian patients [24]. As for Asian populations, no positive relationship was observed between this SNP and esophageal squamous cell carcinoma [23] or esophagogastric junction adenocarcinoma risk in Chinese Han population [22]. From the findings of abovementioned studies, we assumed that BTLA rs1982809 polymorphism might be specific for Caucasians, but not for Asians. However, we observed that BTLA rs1982809 polymorphism elevated the risk of BC in Chinese women in this study. Fu et al. revealed that BTLA gene polymorphisms were connected to the intensified risk of BC in Chinese women [24]. Nevertheless, 
they did not investigate rs1982809 polymorphism [24]. Honestly, this was the first Chinese study to observe this finding. Further studies in other Chinese populations should be conducted to verify the findings of this study.

In addition, we performed subgroup analyses, and revealed that BTLA rs1982809 polymorphism enhanced the risk of $\mathrm{BC}$ in premenopausal women and those aged < 55 years old. Thus, we should pay more attention to those populations who had mutation of this SNP, because these individuals were more prone to the occurrence of BC. Last, we observed that BTLA rs1982809 polymorphism was associated with the ER status, Ki-67 status, C-erbB-2 status, TNM stage and tumor size of BC patients, suggesting that this SNP was significantly associated with the clinical manifestations of BC. It is worth noting that other SNPS of BTLA gene were also shown to be related with some clinical features of $B C$ in Chinese women from Heilongjiang Province [33].

This study had several limitations. One, the sample size was not large enough. Two, the findings of this study might not be not applicable to other races, because all enrolled individuals were Chinese. Three, we only investigated one SNP of BTLA gene. Four, whether BTLA rs1982809 polymorphism was associated with the gene and protein levels is unknown. Five, whether this SNP affected the prognosis of BC needs further investigation. Six, the biological functions of rs1982809 polymorphism remained to be explored. Last, the interaction between this polymorphism and environmental factors should be considered.

Collectively, this case-control study observes that BTLA rs1982809 polymorphism is remarkably associated with higher risk and clinical manifestations of BC in Chinese females. Further retrospective studies are needed to validate these findings.

\section{Abbreviations}

BTLA: B and T lymphocyte attenuator; BC: breast cancer; TNM: tumor node metastasis; PD-1: programmed cell death-1; CTLA-4: cytotoxic T lymphocyte antigen-4; HVEM: Herpes virus entry mediator; ORs: odds ratios; 95\% Cls: 95\% confidence intervals.

\section{Declarations}

\section{Ethics approval and consent to participate}

The Institutional Review Board of The Affiliated Huaian No.1 People's Hospital of Nanjing Medical University approved this study. Informed consents were obtained from all individuals.

\section{Consent for publication}

Not applicable.

\section{Data availability statement}

The data that support the findings of this study are available from the corresponding author upon reasonable request. 
None

\section{Funding}

No funds.

\section{Author contribution}

Conceptualization: Zhi Li, Jianhua Shi and Ruipeng Zhao; Methodology: Zhi Li, Jianhua Shi and Chang Li.; Software and data analysis: Kang Xu and Wei Song; Validation: Linlin Zhen; Writing - original draft preparation: Zhi Li, Jianhua Shi and Ruipeng Zhao; Writing-review and editing: Zhi Li, Jianhua Shi and Ruipeng Zhao.

\section{Acknowledgements}

None

\section{Author details}

${ }^{1}$ Department of Thyroid and Breast Surgery, The Affiliated Huaian No.1 People's Hospital of Nanjing Medical University, West Huanghe Road, Huaian 223300, Jiangsu, China. ${ }^{2}$ Department of Clinical Laboratory, The Affiliated Huaian No.1 People's Hospital of Nanjing Medical University, West Huanghe Road, Huaian 223300, Jiangsu, China. ${ }^{\#}$ They made equal contributions to this research.

\section{References}

1. Harbeck N, Penault-Llorca F, Cortes J, Gnant M, Houssami N, Poortmans P, et al. Breast cancer. Nat Rev Dis Primers. 2019;5:66.

2. Bray F, Ferlay J, Soerjomataram I, Siegel RL, Torre LA, Jemal A. Global cancer statistics 2018: GLOBOCAN estimates of incidence and mortality worldwide for 36 cancers in 185 countries. CA Cancer J Clin. 2018;68:394-424.

3. Pashayan N, Antoniou AC, Ivanus U, Esserman LJ, Easton DF, French D, et al. Personalized early detection and prevention of breast cancer: ENVISION consensus statement. Nat Rev Clin Oncol. 2020.

4. Waks AG, Winer EP. Breast Cancer Treatment: A Review. JAMA. 2019;321:288-300.

5. Britt KL, Cuzick J, Phillips KA. Key steps for effective breast cancer prevention. Nat Rev Cancer. 2020;20:417-36.

6. Nelson HD, Zakher B, Cantor A, Fu R, Griffin J, O'Meara ES, et al. Risk factors for breast cancer for women aged 40 to 49 years: a systematic review and meta-analysis. Ann Intern Med. 2012;156:635-48.

7. Winters S, Martin C, Murphy D, Shokar NK. Breast Cancer Epidemiology, Prevention, and Screening. Prog Mol Biol Transl Sci. 2017;151:1-32. 
8. Dai J, Lv J, Zhu M, Wang Y, Qin N, Ma H, et al. Identification of risk loci and a polygenic risk score for lung cancer: a large-scale prospective cohort study in Chinese populations. Lancet Respir Med. 2019;7:88191.

9. Fachal L, Aschard H, Beesley J, Barnes DR, Allen J, Kar S, et al. Fine-mapping of 150 breast cancer risk regions identifies 191 likely target genes. Nat Genet. 2020;52:56-73.

10. Grossberg AJ, Lei X, Xu T, Shaitelman SF, Hoffman KE, Bloom ES, et al. Association of Transforming Growth Factor beta Polymorphism C-509T With Radiation-Induced Fibrosis Among Patients With EarlyStage Breast Cancer: A Secondary Analysis of a Randomized Clinical Trial. JAMA Oncol. 2018;4:175157.

11. Schumacher FR, Al Olama AA, Berndt SI, Benlloch S, Ahmed M, Saunders EJ, et al. Association analyses of more than 140,000 men identify 63 new prostate cancer susceptibility loci. Nat Genet. 2018;50:92836.

12. Wu L, Shi W, Long J, Guo X, Michailidou K, Beesley J, et al. A transcriptome-wide association study of 229,000 women identifies new candidate susceptibility genes for breast cancer. Nat Genet. 2018;50:96878.

13. Murphy KM, Nelson CA, Sedy JR. Balancing co-stimulation and inhibition with BTLA and HVEM. Nat Rev Immunol. 2006;6:671-81.

14. Simon T, Bromberg JS. BTLA(+) Dendritic Cells: The Regulatory T Cell Force Awakens. Immunity. 2016;45:956-58.

15. Watanabe N, Gavrieli M, Sedy JR, Yang J, Fallarino F, Loftin SK, et al. BTLA is a lymphocyte inhibitory receptor with similarities to CTLA-4 and PD-1. Nat Immunol. 2003;4:670-9.

16. Nelson CA, Fremont MD, Sedy JR, Norris PS, Ware CF, Murphy KM, et al. Structural determinants of herpesvirus entry mediator recognition by murine B and T lymphocyte attenuator. $\mathrm{J}$ Immunol. 2008;180:940-7.

17. Sedy JR, Gavrieli M, Potter KG, Hurchla MA, Lindsley RC, Hildner K, et al. B and T lymphocyte attenuator regulates $T$ cell activation through interaction with herpesvirus entry mediator. Nat Immunol. 2005;6:908.

18. Liu J, Li J, He M, Zhang GL, Zhao Q. Distinct Changes of BTLA and HVEM Expressions in Circulating CD4(+) and CD8(+) T Cells in Hepatocellular Carcinoma Patients. J Immunol Res. 2018;2018:4561571.

19. Sekar D, Govene L, Del Rio ML, Sirait-Fischer E, Fink AF, Brune B, et al. Downregulation of BTLA on NKT Cells Promotes Tumor Immune Control in a Mouse Model of Mammary Carcinoma. Int J Mol Sci. 2018;19.

20. Partyka A, Tupikowski K, Kolodziej A, Zdrojowy R, Halon A, Malkiewicz B, et al. Association of 3' nearby gene BTLA polymorphisms with the risk of renal cell carcinoma in the Polish population. Urol Oncol. 2016;34:419 e13-9.

21. Karabon L, Partyka A, Jasek M, Lech-Maranda E, Grzybowska-Izydorczyk O, Bojarska-Junak A, et al. Intragenic Variations in BTLA Gene Influence mRNA Expression of BTLA Gene in Chronic Lymphocytic Leukemia Patients and Confer Susceptibility to Chronic Lymphocytic Leukemia. Arch Immunol Ther Exp (Warsz). 2016;64:137-45. 
22. Tang W, Chen S, Kang M, Liu J, Liu C. Investigation of BTLA tagging variants with risk of esophagogastric junction adenocarcinoma. Biosci Rep. 2019;39.

23. Cao R, Tang W, Chen S. Association between BTLA polymorphisms and susceptibility to esophageal squamous cell carcinoma in the Chinese population. J Clin Lab Anal. 2020;34:e23221.

24. Khadhraoui C, Kaabachi W, Tritar F, Daghfous H, Hamzaoui K, Hamzaoui A. Association of BTLA rs1982809 polymorphism with lung cancer risk in Tunisian population. Int J Immunogenet. 2020.

25. del Rio ML, Lucas CL, Buhler L, Rayat G, Rodriguez-Barbosa JI. HVEM/LIGHT/BTLA/CD160 cosignaling pathways as targets for immune regulation. J Leukoc Biol. 2010;87:223-35.

26. Mintz MA, Felce JH, Chou MY, Mayya V, Xu Y, Shui JW, et al. The HVEM-BTLA Axis Restrains T Cell Help to Germinal Center B Cells and Functions as a Cell-Extrinsic Suppressor in Lymphomagenesis. Immunity. 2019;51:310 - 23 e7..

27. Shui JW, Steinberg MW, Kronenberg M. Regulation of inflammation, autoimmunity, and infection immunity by HVEM-BTLA signaling. J Leukoc Biol. 2011;89:517-23.

28. Celis-Gutierrez J, Blattmann P, Zhai Y, Jarmuzynski N, Ruminski K, Gregoire C, et al. Quantitative Interactomics in Primary T Cells Provides a Rationale for Concomitant PD-1 and BTLA Coinhibitor Blockade in Cancer Immunotherapy. Cell Rep. 2019;27:3315-30 e7.

29. Lan X, Li S, Gao H, Nanding A, Quan L, Yang C, et al. Increased BTLA and HVEM in gastric cancer are associated with progression and poor prognosis. Onco Targets Ther. 2017;10:919-26.

30. Li X, Xu Z, Cui G, Yu L, Zhang X. BTLA Expression in Stage I-III Non-Small-Cell Lung Cancer and Its Correlation with PD-1/PD-L1 and Clinical Outcomes. Onco Targets Ther. 2020;13:215-24.

31. Song J, Wu L. Friend or Foe: Prognostic and Immunotherapy Roles of BTLA in Colorectal Cancer. Front Mol Biosci. 2020;7:148.

32. Zhang RR, Wang LM, Shen JJ. Overexpression of miR-32 inhibits the proliferation and metastasis of ovarian cancer cells by targeting BTLA. Eur Rev Med Pharmacol Sci. 2020;24:4671-78.

33. Fu Z, Li D, Jiang W, Wang L, Zhang J, Xu F, et al. Association of BTLA gene polymorphisms with the risk of malignant breast cancer in Chinese women of Heilongjiang Province. Breast Cancer Res Treat. 2010;120:195-202. 